\title{
Communicative Approach: An Alternative Method Used in Improving Students' Academic Reading Achievement
}

\author{
Noer Doddy Irmawati ${ }^{1,2}$ \\ ${ }^{1}$ Faculty of Postgraduate Study \& Faculty of Letters, Ahmad Dahlan University (UAD) Yogyakarta, Indonesia \\ ${ }^{2}$ School of Multi Media Technology and Communication, Universiti Utara Malaysia, Malaysia \\ Correspondence: Noer Doddy Irmawati, Sisiran2 No4 Taman Siswa UUM, Jitra 06000, Kedah Darul Aman, \\ Malaysia. Tel: 60-135-977-518 / 60-134-708-727. E-mail: noer_doddyirmawati@yahoo.com
}

Received: April 10, 2012 Accepted: April 22, 2012 Online Published: July 1, 2012

doi:10.5539/elt.v5n7p90 URL: http://dx.doi.org/10.5539/elt.v5n7p90

The research is financed by Ahmad Dahlan University, Jln. Kapas No.9-Semaki, Yogyakarta, Indonesia.

\begin{abstract}
Academic reading is a difficult subject to be mastered. It is needed because most of books or references are written in English. The emphasis is on academic reading which becomes a compulsory subject that must be taught and understood in Faculty of Letters UAD Yogyakarta. Communicative approach is used and applied as an alternative method in the process of teaching-learning that focuses on language as a medium of communication. Communication ability involves in understanding fully the vocabulary, grammar, comprehension, and all aspects of English skills such as reading, listening, speaking and writing.

One main focus of the classroom action research that appears from communicative approach which is applied in the process of teaching-learning academic reading will be discussed. The objectives are (1) How is the application of communicative approach?, (2) How far is the influence of using communicative approach in teaching academic reading? It includes the study intensity of the students, the benefit and the weakness of using the approach.

The results showed the application of communicative approach effectively improved the students' ability in academic reading. It could be seen from the improvement of some aspects, (1) aspects of reading ability, (2) aspects of English: vocabulary, grammar, pronunciation, communication, and ability of cooperation, colaboration, socialization, sharing ideas, opinion, and suggestion. The objective of teaching, the model of syllabus, the form of teaching-learning activity, and the kinds of learning material used by the teachers were consistent with those which were recommended by communicative approach.
\end{abstract}

Keywords: communicative approach, academic reading, application, influence, achievement

\section{Introduction}

\subsection{Communicative Approach}

"Communicative Approach in language learning is an approach that is used in learning the second language or foreign language that emphasizes on the improvement of communicative ability", that is "the ability of applying the language principle in order to produce grammatical sentences and understand 'when, where, and to whom' the sentences used" (Richard, 1997). Communicative method focuses on language as a medium of communication. It recognises that communication has a social purpose - learner which has something to say or find out." Communication embraces a whole spectrum of functions and notions" (Richards, Jack C. \& Rogers, Theodore S., 2001).

Michael Canale said that "communicative ability is formed by four competences: 1) grammatical, 2) sociolinguistic, 3) discourse, and 4) strategy". Grammatical competence relates to language system mastery, such as: 'vocabulary, word formation, and sentence meaning'. Sociolinguistic competence is a competence to understand and produce accurate utterance in accordance with the context in which the utterance happen. Discourse competence relates to the ability in combining the form and the meaning of a language. Besides to understand the kinds of discourse which is cohesive and coherence. Strategy competence refers to the ability of overcoming the obstacles and simultaneously improving the effectiveness of communication (1983: 6-10).

Communicative approach is much more pupil—orientated, because dictated by pupil's needs and interests. Communicative approach seeks to personalise and localise language and adapt it to interests of pupils. Communicative approach seeks to use authentic resources, more interesting and motivating. In foreign language 
classroom authentic texts serves as partial substitute for community of native speaker. Newspaper and magazine articles, poems, annuals, recipes, telephone directories, videos, new bulletins, discussion programmes - all can be exploited in variety of ways (Richards, Jack C. \& Rogers, Theodore S., 2001).

Communicative approach was developed in the 1980s as a reaction to grammar based approaches. It is an approach for second and foreign language teaching which mainly focuses on developing communicative competence. This approach emphasizes the use of language for meaningful purposes in authentic situation.

The main principles of communicative approach include: 1) goal of effective communication, 2) learning language by using it to communicate, 3) focus on meaning and appropriate usage, 4) focus both on fluency and accuracy, 5) use of authentic materials to reflect real life situation, and 6) integration of four skills (speaking, writing, reading and listening) (Retrieved, 2010).

It can be concluded that Communicative Approach is one of the important approaches to help learners to be able to contact with others in order to talk fluency and to express about themselves confidently and to present many social issues in their environment as quick as possible. As what Littlewood said that "Communicative Approach in the language learning pays attention to the language structural aspects and its functional aspects". "Language structural aspects focus on language form grammatically, while language functional aspects relate to the functions of language form itself" (Littlewood, 1988).

\subsection{Communicative Approach and Tasks}

Communicative Approach includes Task is used in teaching academic reading. The concentration is on the need of the students and the task given is well prepared. The Task which is given to the students is taken from all aspects of academic reading. They are done in the classroom in a group discussion. Each group consists of 5 students. The students are active in speaking English, giving opinion, sharing ideas, discussing some aspects of reading for academic purposes.

Task is given to the students by means of treatment into three cycles. Each cycle has five meetings. In giving the task there is an activity that should be done by the students. The Task consists of three aspects: 1) fluency, 2) accuracy, and 3) complexity. It includes classifying, predicting, inducing, taking note, concept mapping, questioning, personalizing, brainstorming, reflecting, and authentic assessment.

Students, in doing the tasks are claimed by active participation, diligent, hard-working, and able to communicate, brave to propose opinion, and brave to speak English. The more serious of the students in doing the tasks, the more active they use the language. All the activities will give influence to the students in improving the ability of reading for academic purposes in the cognitive, affective, and psychomotor aspects.

David Nunan (Nunan, 1991a \& 1991b) gives the definition of task, he said that task is:

"a piece of classroom work which involves learners in comprehending, manipulating, producing or interacting in the target language while their attention is principally focused on meaning rather than form. The task should also have a sense of completeness, being able to stand alone as a communicative act in its own right".

Nunan's definition includes the pedagogic perspectives. Tasks follow by the using of communicative language and some activities which relate directly to the meaning rather than to the form of language skills as well as activities to help them discover the main aspects in reading.

Further, Nunan (2004) said:

"A pedagogical task is a piece of classroom work that involves learners in comprehending, manipulating, producing or interacting in the target language while their attention is focused on mobilizing their grammatical knowledge in order to express meaning, and in which the intension is to convey meaning rather than to manipulate form. The task can develop skills and strategies for using language to communicate meaning as effectively as possible in concrete situations. It can improve the ability of the students in comprehending as high a degree as possible of linguistic competence".

\subsection{Academic Reading}

Academic Reading is an advanced course in reading designed to help tertiary-level students familiarize themselves with particular aspects of academic reading such as definitions, generalizations, hypotheses, and claims with or without evidence. In addition, it familiarizes students with certain aspects of academic discourse. These include syntactic sequences and words that are frequently used in academic discourse, especially sentence-initial grammatical sequences ..." (Halliday \& Hasan., 1996).

A course in Reading for Academic Purposes (RAP) usually includes activities to help students consolidate academic 
language.

Table 1. The Aspects of Academic Reading in RAP (Cunningsworth, 1984) (Halliday \& Hasan., 1996)

1. Thesis sentence
2. Main Idea
3. Main Idea and supporting details
4. Reference
5. Inference/implication
6. Comparison/contrast
7. Analogy/simile
8. Definition
9. Nonlinguistic Information
10. Generalization
11. Classification
12. Description
13. Hypothesis
14. Claim + evidence
15. Argument and its sequencing
16. Writer's approach/opinion/intention
17. Textual Cohesion

The purpose of studying Reading is that the students are mastering the four abilities in English (reading, speaking, listening \& writing) especially reading for academic purposes (RAP). The emphasize is on RAP because in studying English it has an important role as long as the students study in the university. The most important role is reading because they have to understand some references which are written in English. RAP is different from reading in general, because in understanding the information from reading some references, students need to master reading ability in high level such as to write Paraphrase, Summary, Generalizations, Hypotheses, Transcoding, etc. In related to this statement, Halliday \& Hasan (1996) said that:

"RAP is an advanced course in reading designed to help tertiary-level students familiarize themselves with particular aspects of academic reading such as definitions, generalizations, hypotheses, and claims with or without evidence. In addition, it familiarizes students with certain aspects of academic discourse. These include syntactic sequences and words that are frequently used in academic discourse, especially sentence-initial grammatical sequences such as This study attempts to ..., The findings of this study state that ..., and there is considerable evidence to support that ..., and logical connectors and conjunction".

\subsection{The Application of Communicative Approach}

There are six dimensions: (1) Purpose of study, (2) Syllabus Model, (3) The Form and Procedure of teaching-learning activities, (4) The Kind and Function of learning materials, (5) Learner's role, and (6) Students' role in teaching-learning process.

\subsubsection{Purpose of Study}

The purpose of studying academic reading is to master the reading ability as well. Students understand the reading material, reading strategy, textual meaning and implied meaning of the texts, develop reading skills, and get the writer's idea. It is hoped that they are able in speaking English, discussing in English and retelling story. To reach the goal, Student-Centered Learning (SCL) Strategy is used. It means that the students are given chance to communicate in English freely.

\subsubsection{Syllabus Model}

Learning materials are arranged based on language skills and theme which become the context of improving reading skills. The themes are taken from RAP aspects which consist of 'Thesis sentence', 'Main Idea \& Supporting Details', 'Reference \& Inference', 'Comparison \& Contrast', 'Generalization', 'Classification', and 'Description'.

\subsubsection{The Form and Procedure of Teaching-Learning Activities}

The form of teaching-learning activity is task-based instruction. Lecturer gives task and instruction to the students, the students do the task in a group consists of 4 . The procedure of reading activity consists of three steps: pre-reading, 
whilst-reading, and post-reading activities. All the activities and analysis are done simultaneously and integrated. Reading skills used are Skimming, Scanning, Reading for detailed information, Reading between the lines, Predicting, and Deducing the meaning from context. In teaching grammar, lecturer uses Exposure, Generalization, Reinforcement, and Application techniques.

\subsubsection{The Kind and Function of Learning Materials}

It is a kind of task-based learning, so the materials are prepared by giving tasks like: understanding the content of reading text, observing the reading text, arranging disorderly words become good sentences, understanding the vocabulary. The learning materials are functioning as facility of teaching-learning process. Reading material is functioning as a medium to improve the ability of reading and speaking. It is emphasized on the use of language to communicate.

\subsubsection{Learner's Role}

Lecturer becomes a facilitator who helps students in finding a solution of a problem. The duty is giving task, explaining the way to finish the task, motivating the students, guiding the students in finishing the task, controling the class, leading the class, evaluating the activities and the result of learning, and testing them.

\subsubsection{Students' Role in Teaching-Learning Process}

Students do the activity in teaching-learning process. The role of the students moves from proactive and full of initiative becoming robot who only do the tasks given, but sometimes they are serious. The negative side of doing this activity is that they sometimes speak into Indonesian language. They do not speak in English.

\subsection{The Influence of its Application}

The influence of using communicative approach to the teaching-learning process is the activity of the students' learning in the classroom in the form of active speaking English every time. They discuss in English, they are active in reading, listening, speaking, and writing. Learning activity is limited to the activity which can be observed. The focus of the research is the teaching-learning in the classroom, not the result of their study. If the result of students' learning mentioned here, it is only as a secondary quality. Learning the axiom of language like spelling, grammar, and vocabulary is not the objective of learning but it is only a supporter of its activity. There are four language skills: reading, listening, speaking, and writing skills. The first two skills is called receptive skill and those two last skills are called productive skill.

The skills and the activities are:

\subsubsection{Reading Skill}

a) to guess the meaning of word based on the context used

b) to determine the main idea of a reading text

c) to differentiate the fact and idea in the reading text

\subsubsection{Listening Skill}

a) to give answer of the oral questions about a topic

b) to fulfill the chart/table based on the oral information

c) to do the task based on instruction given orally

\subsubsection{Speaking Skill}

a) to give questions and answers of a topic

b) to report the result of the discussion

c) to share opinion about something important

\subsubsection{Writing Skill}

a) to make summary of reading text

b) to write the answer in order to understand the text

c) to write a formal letter and an individual letter in a good and right form.

All the indicators mentioned above became the specific learning purpose which was used as a starting point of learning activity using communicative approach in the classroom.

Communicative activity was suitable for the students who had the ability of language understanding like grammar and 
vocabulary, but it was not suitable for the students who did not have the ability yet. That was why Littlewood proposed pre-communicative activities which divided into structural and quasi-communicative activities (Littlewood, 1988).

Richards and Nunan (Richards, Jack C. \& David Nunan, 1990) said that "a teaching-learning process is good and shows the good structure if the purpose of study and the activity to reach the goal are clear enough to be understood by the students, so that the lecturer needs to explain it again and again to the students in order they understand".

Cotterall and Crabbe (Cotterall, Sara \& David Crabbe., 1992) also said about the same statement as what Richards and Nunan said. They added that "the students will be stand alone if they are aware of the importance of their purpose of learning". The same statement was also said by Tukinoff, Berliner, and Rist (Brown, 2001) that "the purpose of finishing the task and the purpose of learning might be understood well by the students, but sometimes in between the lecturer and the students did not aware of them".

Communicative approach gave positive influences to the teaching-learning process. It brought the students active in speaking English, understanding the meaning of words, comprehending the reading texts, doing the tasks, and studying well. By doing the task the students could practice together in speaking English actively, productively, and receptively. But there were three factors that made the teaching-learning were not effective: (1) All students did not involve actively in doing and finishing the tasks, (2) All the result of doing the task were not always discussed intensively, (3) Lecturer's domination in the teaching-learning activity was still prominent.

\section{Study Focus}

The study reported here focuses on the benefit of Communicative Approach that could be used as an Alternative Method in Improving Students' Academic Reading Achievement. Communicative Approach was selected in teaching RAP because it could improve student's learning activities, especially in using the language directly to read, speak, communicate, debate, argue, exchange ideas, discuss, especially in improving reading skills in English and understanding the content of academic reading. Moreover, seeing the fact and based on the reality that the students' English achievement especially students' ability of RAP in Faculty of Letters Ahmad Dahlan University Yogyakarta was Low, so the writer proposed Communicative Approach to be used in teaching academic reading. The low achievement might be caused by (1) low input quality, (2) the weakness of English basic ability, (3) unrelevant syllabus, (4) the conventional of learning method, and (5) students' attitude toward the difficulty of English. Communicative Approach was used in the teaching-learning process because it could make students using English to do the tasks given, besides language input could be intensive and students would actively involve in the process of learning. Communicative Approach here followed by meaningful principle that learning would improve if the subject was relevan to the need of the students. By using the language actively the improvement of students'academic reading achievement would increase.

\section{Research Question}

There were two research questions to be answered through the research: 1) How is teaching reading by applying communicative approach? And 2) How far is the influence?

To find the answers of those two questions, the researcher carried out the research process by finding the data first. The data were taken by giving pre-test, doing observation by active participation, deep interview, and giving task. The test was given to 27 students which consisted of 9 boys and 18 girls. One of them was Thailanese and the rest were Indonesian. They were about $19-20$ years old. The basic of their English was mostly the same.

Data gathering was undertaken within a period of two months, between January and February 2010 as school commenced in January. To complete the primary data the researcher did the document analysis such as the sertificate, learning report, papers and result, identity form, and students' document. Instrument which was refered to David Nunan (2004) such as "observation form, field note, and data analysis form were also used to state the realibility of the research".

\section{Phases of the Study}

This was the result of a Classroom Action Research (CAR) which focused on the effort to change the real condition now to the wish condition. It was done by using cyclic collaboration consisted of planning, acting, observing, and reflecting. According to Raka Joni (Raka Joni, 1998) there were three characteristics of CAR: (1) inquiry reflective which was based on practice driven and action driven of the spesific and contextual problems. The purpose was to repair the praxis directly here and now; (2) collaborative which was used to do together the teaching-learning process from the planning, acting, observing/evaluating, up to the reflecting as a whole in order to get the aim in improving the result as well; and (3) reflective which was done continuously in order to get the clarification and justification about the progress, improvement, decline, the lack of effectiveness of the action. 
It was done by following four steps: (1) Planning consisted of action plan: problem identification, instrument compilation, coordination with the team; and action preparation: simulation, coordination, and discussion; (2) Action Implementation: Preparing cycle 1-3, and arranging the action; (3) Observation which was done continuously from action to action, and taking note; (4) Reflection in order to have a suitable treatment and learning materials.

As what mentioned above that CAR had three main characteristics, namely: (1) reflective inquiry, (2) collaborative, and (3) reflective. So in the research all of the three main characteristics of CAR were applied and done:

\subsection{Reflective Inquiry}

CAR departed from the real learning problems that faced daily by lecturersand students. Thus, research activities were based on the implementation of the task (practice driven) and decision of action to solve problems encountered (action driven). The problem that the focus was specific and contextual problems. CAR objective was to improve the practice directly, here and now (Laurence, 1998).

\subsection{Collaborative}

Efforts to improve the process and learning outcomes could not be done alone by the lecturer, but he might collaborate without her professors. CAR was a joint effort of various parties to achieve the desired improvements. Collaboration might be shown in the overall planning process, implementation of the CAR (planning, implementation measures, observation-evaluation, and reflection), up to preparation of research reports.

\subsection{Reflective}

CAR had a special characteristic, namely sustainable reflective attitude. CARmore emphasized on the process of reflection on the process and results of ongoing research to get an explanation and justification of progress, improvement, deterioration, lack of effectiveness, and so on from the implementation of an action could be utilized to improve the processes used on cycles of action other activities.

\section{Observation}

Observations were always made to obtain observations associated with the development of the action that was taken each cycle in class. Any observations were well documented and completed by the next job that an act supported the direction of change in performance improvement. Observations were carried out continuously in the classroom interaction. By carrying out direct observations, the picture of the actual circumstances of what happened in the teaching-learning process would be obtained. Based on the field observation, it could be seen the variety roles of lecturer such as: giving tasks, explaining the way to do the tasks, controling the students' behavior and evaluating students' learning result. Those roles were important to be played in order that the students could study well and seriously. There was a good question, "Could the coming of those roles guarantee a good learning process happen?". "We did not know". Those roles must be done appropriate and match with the purpose of the study.

Based on the observation obtained, there were several roles that must be presented by lecturer but they were not done as well: the explanation about the purpose of learning, the basic of giving tasks, the relationship between tasks which are done by the students, and the scope of discussion and learning. So the consequence was that the students did not understand the reason why they did the tasks so that the class activity was done mechanically. Richards and Nunan (1990) said that "a teaching-learning process is good and shows the good structure if the purpose of study and the activity to reach the goal are clear enough to be understood by the students, so that the lecturer needs to explain it again and again to the students in order they understand".

Soedijarto (1993) said that "Students' participation level in the teaching-learning process is mostly determined by the lecturer's effort as a class leader to make them dynamic". It depends on the method used and the style of teaching. There are two approaches that can be used: (1) the basics of learning material and (2) theory. The implementation of learning techniques must be in line with the lesson plan and approaches used.

\section{Interview}

Deep interview was really carried out and given to the lecturer, collaborator, head of the department, and students. Deep Interview was benefit to explore further the understanding of the communicative approach, the special characteristics and how to apply communicative approach in the teaching-learning process. Lecturer was also interviewed several times during the study. The first interview was given to the lecturer to obtain the data about himself, background, and mission. The second interview regarding the understanding and preparation of lecturer to implement the communication approach applied in the teaching-learning process. In-depth interviews were also conducted on several students to uncover the obstacles that they face, and find out the causes of low student achievement on academic reading.

As an example, the following was the result of an in-depth interview with one of the students, who said: 
"Learning English is so hard ma'am. I'm always afraid if I want to talk, I lack of mastering the vocabulary, so if I want to say I always feel so short of words. In addition, every time I remember my grammar and structure I do not pronounce English sentences. If it were so ma'am, it is only boredom, laziness, and fear of being wrong. How is it ......ma'am?"

\section{Profile of the Participants}

The participants of the research were the $4^{\text {th }}$ semester students of English Department, Faculty of Letters, Ahmad Dahlan University, Yogyakarta which was located in Jalan Pramuka 42. A lecturer of academic reading subject named Wajiran who had been working as a lecturer for at least 9 years was also conducted the teaching-learning process using communicative approach. There were 27 students who had different background and came from several places. Their age was around 19-20 years old. The students became the centred of teaching-learning process.

The ability and the condition of the students were also varied, might be caused by (1) low input quality, (2) the weakness of English basic ability, (3) unrelevant syllabus, (4) the conventional of learning method, and (5) students' attitude toward the difficulty of English.

\subsection{The Low Input Quality}

The first factor was the low input quality of the students. According to the result of selection test, they got the score in between 50-55 from the scale of 100. Score in between 50-55 was not enough to be used to improve the ability of RAP.

\subsection{The Low of Basic Ability of the Students}

The second factor was the low of basic ability of students toward English. Based on class observation it could be found that there were many students who made mistake in their basic stucture such as in the using of to be (is, are, am), pronoun (I, me, us, he, his, him, she, her, hers, they, them, their). They were also weak in arranging simple English sentences. Their mistake was in the basic element.

\subsection{The Unrelevan Syllabus}

The third factor was the unrelevan syllabus. The syllabus was not relevan to the need of the students. Lecturer tended to teach by emphazising on the stucture and vocabulary rather than on the other aspect of English. If the teacher taught reading, the texts of reading were taken from general English which were not relevan to RAP. So that the teaching learning RAP was as the same as learning English in Senior and Junior High Schools. Actually there might be related to the university level which proved the need of the students.

\subsection{The Conventional of Method of Teaching and Learning}

The fourth factor was the conventional of method of teaching and learning. According to the result of the discussion among lecturers, it could be seen that there were some methods used by them which were called conventional methods. Lecturers asked students to read some reading materials, to understand the vocabulary, to answer questions. They never asked students to read some academic reading materials. They never asked students to be active in the classroom, so that the students became passive.

\subsection{The Difficult of Students' Attitude toward English}

The fifth factor was the difficult of students' attitude toward English. All students said that English was a difficult subject.

\section{Data Analysis}

The validity of all the data got were tested by using data source trianggulation and method trianggulation. Beside those two trianggulations, validity test technique by carrying out informant review was also used (Sutopo, 1996). It was done by confirming the result of information report which was given such as their communicative ability and the language aspect which was understood based on the fact. Discussion was also used in order to know the difficulty faced by the students and the improvement which was gotten.

Descriptive Statistic Technique and Critical Analysis were used in the research because the data were collected in the form of test results. Descriptive Statistic Technique was used to describe the data of learning achievement in order to know the rank of every cycle. Statistic was the way to know the central tendency, so there would be the mean (M), median (Md), modus (Mo), and standard deviation (SD).

Critical analysis was used in this study because of the implementation of this study includes several dimensions that must be known and monitored such as: development of a genuine state in detail, the results and the changes from one cycle of treatment to others, the decomposition of a point on the various parts and the relationship between the parts to obtain the proper understanding of the overall sense, the issue or problem-solving process that began with the notion 
of a truth. Critical Analysis was also used to find precisely the development of the situation and condition of teaching-learning process. The exact detailed development of the situation and condition, the problems rising from the first up to the third cycles, the result and the change of giving the treatment, the relationship between the parts/activity of the process, and problems solving process were analyzed critically and obviously.

Result evaluation and the assessment of the success of an action became the working indicator of the research. The result of the analysis and action interpretation became the basic of doing the evaluation, determining the success or the assessment of the purpose of the action. The summary of evaluation result became the reference in making decision toward the action. Based on the result of the evaluation, the modification and the stability of the cycle were stated.

The criteria of the success of the action were the condition of the students before and after the treatment. There were two kinds of criteria: normative and absolut, normative meant 'concerning rules' while absolut was 'very great or principle that was true or right in all situations'. To give intention to the development of students achievement after the treatment, a criterion was used that was comparing the development of student's achievement and the minimal standard which was fixed. For axample: if the minimal standard is 66, so if the students get the score above 66 meant that they succeeded in getting the goal.

The other indicator was the quality of teaching-learning process, if there were $75 \%$ students revealed the good ctiterion as the indicator, they were more active and able to communicate in English, capable in following the teaching-learning process, and gave positive improvement, meant that the action was successfully done and the goal was already got.

\section{Findings and Discussion}

In accordance with a number of problems, these findings were divided into two parts: The Findings Concerning the Applications of Communicative Approach in Learning RAP and The Effect of the Application of Communicative Approach in Teaching and Learning.

\subsection{The Findings Concerning the Application of Communicative Approach in Learning RAP}

The Application of Communicative Approach in Learning RAP included six dimensions: (1) learning goals, (2) a model syllabus, (3) the form and procedures for teaching and learning activities, (4) the type and function of the learning materials in teaching and learning activities, (5) the role of faculty in teaching and learning activities, and (6) the role of students in teaching and learning activities.

\subsubsection{Learning Objectives}

According to the lecturer, reading was the learning objectives that students should be able to read well, quickly and precisely. Students were able to understand the reading and were able to communicate using the language they had learned, capable of expressing re-reading as the results of using English actively, real and natural, dare to express opinions in English, particularly verbally.

To achieve these objectives the faculty implemented a strategy of Student-Centered Learning (SCL). Students were given the widest possible opportunity to communicate and speak in English. They were expected to solve problems independently.

\subsubsection{Model Syllabus}

Syllabus was the description and organization of learning material to be taught to the students. It was part of the curriculum which applicable in the study program. Language skills mentioned in the syllabus covered the four skills, namely: listening, speaking, reading, and writing. Meanwhile, the language elements included: grammar, vocabulary, pronunciation, and spelling.

\subsubsection{The Forms and Procedures for Teaching-Learning Activities}

\subsubsection{Form}

The observations showed that teaching-learning activities of reading were task completion form (task-based instruction). Lecturer assigned tasks to the students, and students were working on the tasks. The form of the task was a class activity that required students to use English, to understand or convey a message, either verbally or in writing. Verbal tasks accompanied by a written explanation and written assignments were also accompanied by verbal explanation. Thus, the delivery of a task (verbal and written) was flexible. In learning RAP, tasks were given in the form of reading activity, scanning and skimming the reading texts, answering questions.

"Scanning is a fast reading technique to be used if the reader wants to get information without having to understand the whole text, such as seeking information about a person's birth time. Skimming is a speed-reading technique to be used if the reader wants to know the main ideas of a text". 


\subsubsection{Procedure}

The procedure used in teaching RAP was grouped into three stages, namely the opening stages, implementation stages, and the closing stages. Opening stage, which lasts for three to five minutes for praying, delivering greetings, checking the student's attendance, and preparation of the implementation of teaching and learning activities? The Implementation of teaching-learning activities consisted of three stages namely the stage of pre-reading activity, whilst-reading activity, and post-reading activity. Pre-reading activity was a short reading in a view minutes to find the form, context, content and message in general. Whilst-reading activity was the activity of reading itself. Post-reading activities were activities that were designed as a further act of reading. The goal was to give students a useful new capabilities based on the content of reading. The closing stages served the opportunity to ask, giving homework, summing up, and delivery of gratitude.

\subsubsection{Types and Functions of Learning Materials in Teaching-Learning Activities}

\subsubsection{Types}

In accordance with the forms of teaching-learning activities, learning materials shaped Reading tasks, such as understanding the content of the reading text, listening to an oral discourse to be able to identify errors in a map, and compose sentences into one good irregularly paragraph.

\subsubsection{Function}

Learning material as described above, particularly in the form of duties, serves as a means of streamlining the way of teaching-learning activities in the form of task completion. Completion of the task itself became a means of developing English language skills, both oral and written. Unlike the other subjects in the form of understanding the concept of learning activities, learning Reading was more oriented to use the language skills to communicate. Therefore, in teaching-learning RAP, the reading material served as a medium for the development of reading skills and English as an object of the understanding. The development of English language skills included reading, listening, speaking, and writing. The four skills were supported by the language function. Learning materials were designed according to those needs. There were integrated learning, which became a feature of communicative approach.

\subsubsection{The Role of Lecturer in the Teaching-Learning Activities}

The role of the lecturer can be devided into 6 (six) activities, they were to: (a) deliver the task, (b) explain how to complete the task, (c) motivate the students; (d) guiding the students to dothe task, (e) control the class, and (f) evaluate the students' learning activities and results

\subsubsection{Delivering Task}

The tasks were given orally or in writing. Supported elements to facilitate the delivery and completion of the tasks were given. Introductory and short descriptions toward the tasks were given orally. It might be served smoothly, clearly and understandable.

\subsubsection{Explaining How to Complete the Task}

After delivering the task, especially for written assignments, the lecturer explained how to complete the task orally. Although the explanation given in the task had no clue how to do. With the explanation, students could complete the tasks in a more stable and vibrant.

\subsubsection{Motivating the Students}

The motivation was in the form of verbal expressions such as "Any idea?", "Any group?". The arrival of lecturer could encourage the students to work more seriously.

\subsubsection{Guiding the Students}

Provision of guidance was done by giving clues, either in the form of pieces of an answer, place or source of answers, and other questions that have associations with the desired answer. It was done because not all the questions or tasks assigned by the lecturer could be resolved well.

\subsubsection{Controlling the Class}

Controlling the class was arranged for supporting the implementation of classroom teaching-learning activities. It might be conducted as well as the class became optimally effective and conducive.

\subsubsection{Evaluating the Students' Learning Activities and Results}

The students learning outcomes might be evaluated in order to know the result and the improvement. Assessment was carried out by using two approaches, namely a process approach and the approach of the product (valuation approach). The tasks undertaken during the student teaching-learning process served as an assessment tool. 


\subsubsection{The Role of Students in the Teaching-Learning Activities}

Students were served as the subjects of learning, so they became parties who conducting the activity of teaching and learning. It was reflected in the activities they carried out the tasks which were delivered by lecturers either individually or in groups. The problem was that in certain respects student did not work seriously. They did not do well. They did not form a group as requested, especially for the large groups, and in the group work they did not speak in English, but in Indonesian or Javanese. So working groups which became one of the main features of communicative approach lost its essencial meaning.

\subsection{The Effect of the Application of Communicative Approach in Teaching and Learning}

The focus of attention was the process of student learning in the classroom, not the result of their learning. If the study results presented in this paper, it is only secondary. The reasons underlying these restrictions were that learning English was basically learning to use the language to communicate.

In the implementation of teaching and learning activities the lecturer always gave assignments to the students. To support the completion of these tasks, the lecturer gave instructions on how to do the tasks, gave examples of doing the tasks, monitor student activities during their working, asking them to discuss the results of their work, providing feedback as necessary, and providing an explanation as reinforcement for what they had done and discussed.

From the discussion the terms of the design of the tasks was appeared, communicative approach gave a positive impact on students' learning activities. Communicative approach, which was manifested in the form of teaching and learning, could be understood and the students could communicate effectively. In practice there were at least three factors that make learning reading using communicative approach did not effective, because:

1. Not all students were actively involved in the completion of tasks;

2. Not all tasks had been done and discussed by the students intensively;

3. The dominance of lecturers in teaching and learning activities was very prominent.

To overcome the problems of applying communicative approach, lecturer should have a role as a facilitator and motivator in teaching academic reading. Students should do the tasks given seriously, neatly, correctly, and accordingly. They should be proactive in learning, more responsive and reactive.

\section{Conclusions}

This study describes the results of a classroom action research using communicative approach. It can be stated that communicative approach can be used as an alternative method in teaching academic reading, but it must be applied a little bit strictly because it has some rules to be followed. Lecturer must prepare a curriculum, a syllabus, and a lesson plan as well. All of them must be based on students' need. Lecturer must prepare some tasks. Lecturer must stand straight as a controller when he/she manages the students in the classroom.

The following is the dimensions that must be paid attention in order that the purpose of learning academic reading using communicative approach can be reached:

First is to know and understand the purpose of learning academic reading. The purpose was that the students could understand various reading texts, the idea of reading texts, the vocabularies of reading texts, and they were able to use English as a means of communication. The willing and the ability could be seen from their braveness in speaking English, sharing ideas, discussing, and solving the problems.

Second is the model of syllabus. The syllabus used in teaching academic reading was thematic syllabus. English language skills such as listening skill, speaking skill, reading skill, and writing skill with the supporting elements such as vocabulary, grammar, pronunciation, spelling were presented in the theme as the scope of study. That is why, theme had an important role that was to organize all elements. Theme became a developing context that was used in improving the language skills and reaching the goal of learning RAP.

Third is the form and procedure of teaching-learning activity. The activity of teaching-learning academic reading was in the form of doing the tasks. Lecturer gave tasks to the students and students did the tasks given. By doing the tasks, students learnt how to read the texts, how to understand the story, how to speak English. They had to practice by discussing and doing the task, reading the texts, analyzing the texts, and speaking English. In doing the tasks, students followed three steps of action: pre-reading, whilst-reading, and post-reading activities.

Fourth is the kind and function of learning materials. The material of learning academic reading was tasks that supported by texts and concrete things. The materials were prepared based on students' need and it was a kind of Students' Centred Learning (SCL). Those three learning materials were functioned as a means to speed up the process of teaching and learning. Tasks might be well prepared and might be done by the students in the classroom in order 
they could learn, understand, and use the language as well.

Fifth is the lecturer's role in teaching-learning activity. There were at least seven activities that might be done by lecturer in every meeting: (1) Preparing tasks, (2) Giving tasks, (3) Explaining the way to do the tasks, (4) Motivating the students, (5) Conducting the students to finish the tasks, (6) Controlling the students' activity, and (7) Evaluating the result of teaching-learning process.

Sixth is students' role in the teaching-learning activity. It could be found that the students' participation in the classroom was develop. It could be seen from the condition of the students and the result of their study from the first to the third cycles. They gave a good response toward the tasks given. They did the task actively and the result of doing the tasks was also significantly increase. They discussed and did the tasks seriously, they had done their best. The students communicated each other in English.

The improvement of Reading Achievement by using Communicative Approach could be reached. It could be seen from the result of teaching-learning process which was done in English Letters Department Faculty of Letters Ahmad Dahlan University Yogyakarta by giving treatment to the three cycles in one semester from February to July 2010. Based on pre-test and post-test in every cycle, the significantly improvement result of the achievement of the students could be seen:

Table 2. The Result of The Test

\begin{tabular}{lllllll}
\hline & \multicolumn{5}{c}{ Test on Cycle I, Cycle II, and Cycle III } \\
\cline { 2 - 7 } Score & Pre-Test & Post-Test & Pre-Test & Post-Test & Pre-Test & Post-Test \\
\hline Lowest & 48 & 43 & 52 & 56 & 52 & 58 \\
Highest & 72 & 83 & 81 & 79 & 79 & 88 \\
Mean & 57.41 & 65.22 & 62.41 & 66.27 & 66.62 & 75.30 \\
\hline
\end{tabular}

There were 27 students who followed Academic Reading. From 27 students, 7 students got the high score A, 11 students got $\mathrm{B}$ score, 8 students got $\mathrm{C}$ score and 1 student got $\mathrm{D}$ score.

In observing the principles of Communicative Approach there were positive and negative influences. The dimensions of the purpose of study, model syllabus, the form and procedure of teaching-learning process are suitable with the principle of the method. While the intensity of teaching-learning activity, the quality of lecturer's role, and the quality of students'role were not suitable yet. It caused the failure of the teaching-learning process.

In related to the above discussion, it can be summarized that the application of communicative approach in teaching academic reading must be well done in accordance with the principle. If there is a good planning but the application is not good the result is also bad. The bad influence of applying communicative approach in English Letters students who follow Academic Reading can be seen from three indicators: (1) the implication of the approach is not so good it is proven by the fact that the approach is not effective to be used to improve the ability of the students. The students do not involve actively in doing and finishing the task; (2) The answers and the works of the students are not discussed and analyzed intensively; and (3) The domination of the lecturer in the teaching-learning process is still prominent.

\section{References}

Brown, H. D. (2001). Teaching by Principles. An Interactive Approach to Language Pedagogy (2nd Ed). New York: A.W. Longman, Inc.

Canale, M. (1983). From Communicative Competence to Communicative Language Pedagogy, Language and Communication. London: Longman.

Cotterall, Sara, \& David Crabbe. (1992). Fostering Autonomy in the Language Classroom: Implications for Teacher Education, Guidelines, 14(2), December, 11-22. Singapore: RELC.

Cunningsworth. (1984). Evaluating and Selecting EFL Teaching Materials. London: Heinemann.

Hasan., H. (1996). Reading for Academic Purposes. London: Cambridge University Press.

Laurence, J. (1998). Learning Resources for TeachingTeaching. Toronto, Ontario: Green Dragon Press.

Littlewood, W. (1988). Communicative Language Teaching: An Introduction. Cambridge: Cambridge University Press.

Nunan, D. (1991a \& 1991b). Language Teaching Methodology. New York: Prentice Hall. 
Nunan, D. (2004). Task-Based Language Teaching. A Comprehensively Revised Edition of Designing Task for the Communicative Classroom. Cambridge: Cambridge University Press.

Raka Joni, T. (1998). Penelitian Tindakan Kelas: Beberapa Permasalahannya. Jakarta: PCP PGSM Ditjen Dikti.

Richards, Jack C., \& David Nunan. (1990). The Dilemma of Teacher Education in Second Language Teaching, Second Language Teacher Education (ed). Cambridge: Cambridge University Press.

Richards, Jack C., \& Rogers, Theodore S. (2001). Approaches and Methods in Language Teaching (2nd Ed). Cambridge: Cambridge University Press. http://dx.doi.org/10.1017/CBO9780511667305

Richards, Jack C., \& Rogers, Theodore S. (1997). Approaches and Methods in Language Teaching. Cambridge: Cambridge University Press.

Soedijarto. (1993). Memantapkan Sistem Pendidikan Nasional. Jakarta: PT. Gramedia Widiasarana Indonesia.

Wikipedia. (n.d.). Retrieved March 12, 2010, from http://editthis.info/wiki/Communicative_Approach

\section{Author}

Dr. Hj. R. A. Noer Doddy Irmawati, Dra., M.Hum

She is a government lecturer posted at Ahmad Dahlan University (UAD) Yogyakarta. She was born in Sidoarjo Surabaya on May 26, 1952. She completed her education at Udayana University, Denpasar - Bali for her Doctoranda degree in English Letters. She continued her study at Gadjah Mada University Yogyakarta, American Studies for her Magister degree. She got her Doctor $(\mathrm{PhD})$ degree from Sebelas Maret University Surakarta - Solo in Applied Linguistics majoring English Language Teaching (ELT). She is a Senior Lecturer in UAD Yogyakarta and now acting as a Visiting Lecturer in Universiti Utara Malaysia (UUM). 